\title{
Andinopatagonian species of Plagiochila (Plagiochilaceae, Marchantiophyta). I. Sectio Oligodontes Carl, II. Sectio Flexicaules Carl and III. Sectio Longiflorae Carl
}

\author{
Gabriela G. HÄSSEL de MENÉNDEZ
}

\begin{abstract}
Museo Argentino de Ciencias Naturales "Bernardino Rivadavia”, Av. A. Gallardo 470, C1405DJR Buenos Aires, Argentina, e-mail: hassel@macn.gov.ar
\end{abstract}

\begin{abstract}
Three monotypic sections of Plagiochila are discussed, described and illustrated: Sectio Oligodontes Carl with P. lophocoleoides Mont., Sectio Flexicaules Carl with P. flexicaulis Mont. and Sectio Longiflorae Carl with P. longiflora Mont. ex Gottsche.
\end{abstract}

Key words: Plagiochila, Oligodontes, Flexicaules, Longiflorae, Plagiochila lophocoleoides, P. flexicaulis, $P$. longiflora, Chile - Argentina.

Resumen: Se discuten, describen e ilustran tres Secciones monotípicas de Plagiochila, Sección Oligodontes Carl con Plagiochila lophocoleoides Mont., Sección Flexicaules Carl con Plagiochila flexicaulis Mont. y Sección Longiflorae con Plagiochila longiflora Mont. ex Gottsche.

Palabras clave: Plagiochila, Oligodontes, Flexicaules, Longiflorae, Plagiochila lophocoleoides, $P$. flexicaulis, $P$. longiflora, Chile - Argentina.

\section{INTRODUCTION}

Studies on the andinopatagonian species of Plagiochila were started by the author (Hässel de Menéndez 1983) in relation to the identity of specimens collected in the Chilean channels islands (Hässel de Menéndez \& Solari 1985).

Carl (1931: 118), has shown that a great number of sections of the genus Plagiochila are present in the "valdivian" and the "patagonianfueguian" forest area, from which also a number of endemics are known. They comprise species that are distinguished by special noteworthy characters and therefore are very interesting. Carl mentioned in particular some groups which are distinguished by their extreme and opposite forms (habitus), which have been dealt with recently by the author: Sect. Robustae Carl emend. Hässel, Sect. Equitantes (Hässel de Menéndez 2004a), Sect. Obcuneatae (Hässel de Menéndez 2004b), Sect. Hirtae Carl, Sect. Angulatae Carl (Hässel de Menéndez 2006), and Sect. Chilenses Carl (Hässel de Menéndez 2008).
In this study are included three monotypic sections:

\section{Sectio Oligodontes Carl, Ann. Bryol. Suppl. 2: 130, 1931.}

Lectotype species. Plagiochila lophocoleoides Mont. ( $=$ P. oligodon Mont.)

Plants delicate, pale green, with subtrapezoidal leaves without cnemis, at apex with 2-3 curved unequal teeth; the lamina with wide cell reticulum; the cells with trigones. Rhizoids on stem under ventral insertion arch of leaves. Perianth stipitate, nearly cylindrical, mouth entire except for few apicula.

Discussion. Carl (l. c.) described the parallel leaf margins, that are widened towards their bases, the few apical teeth and the wide cell reticulum of the lamina with thickened trigones. He included $P$. oligodon Mont. (having seen Gay's specimen) and P. lophocoleoides Mont. (on a specimen from Chile collected by Hollermayer). These two names were considered by Hässel de Menéndez (1983:110) to belong to the same species. 
Plagiochila lophocoleoides Mont. Ann. Sci. Nat. ser. 3 (4): 348, 1845.

(Figs. 1-2, 6 A, 7 A-B)

Typus. Chile, Gay (PC! holotypus).

= P. oligodon Mont., Ann. Sci. Nat. ser. 3(4): 348, 1845.

Typus. "ad Hypopterygium" (PC!, BM!, W! herb. Lindenberg 571, isotypi).

$=P$ savatieriana Besch \& C. Massal., Bull. Mens. Soc. Linn. Paris 1: 627, 1886 (1889).

Typus. I. Tres Montes. baie Otway, Savatier 1780 (2) (VER!, FI!, isotypi).

$=P$. difficilis Steph., Kongl. Svenska Vetensk.-Akad. Handl. 46 (9): 28, 1911, p. p.

Typus. Patag. occid. ad truncos, Halle \& Skottsberg 29VI-1908, part a (UPS! lectotypus nov.) (here designated); see Hässel de Menéndez (1983: 97).

$=P$. pudetensis Steph., Kongl. Svenska. Vetensk. - Akad. Handl. 46 (9): 33, 1911, p. p.

Typus. Chiloé, Río Pudeto, ad loc. San Antonio dicto Halle \& Skottsberg 17-VII-1908, part c (UPS!, S!); see Hässel de Menéndez (1983: 115).

$=$ P. bispinosa var. angustifolia Herzog, Beih. Bot. Centralbl. 60 B (1-2): 3, 1939, p. p.

Typus. Westpatagonien, Waldhagen, Puyuhuapi am Rand des Talsumpfes an Arrayanstamm, Schwabe 79 p. p. 9-II-1938, part c (JE!); see Hässel de Menéndez (1983: 93).

Illustrations. Bescherelle \& Massalongo (1889) pl. I, fig. IV, as Plagiochila savatieriana Besch. \& C. Massal.; Dugas (1929) fig. 85, as Plagiochila oligodon Mont.; Dugas (1929) fig. 86; Schiffner (1889) pl. I, fig. 8, as Plagiochila savatieriana Besch. \& C. Massal.; Stephani (1911) fig. 12 a, typus of Plagiochila difficilis Steph.

Description. Plants pale green, shiny when dry, up to $10 \mathrm{~cm}$ long, $3 \mathrm{~mm}$ wide between leaves, forming flat, loose, dense carpets over substrate. Stem straight to slightly zigzag, with lateral intercalary branches of the Plagiochila type, most frequently diverging at $90^{\circ}$; without stolons, plano-convex, about $136 \mu \mathrm{m}$ wide, $117 \mu \mathrm{m}$ thick, 8-9 cells in diam.; cortical cells with thickened walls in 1 stratum $12-14 \mu \mathrm{m}$ in diam., medulla cells with thin walls, 9-12 $\mu \mathrm{m}$ in diam.; ventral merophyte 1-3 cells wide. Leaves close to each other or distant, with long oblique insertion and short ventral inverted $U$ shaped, expanding at $45^{\circ}$ from the stem, curved rectangular, without cnemis, nearly equal in size along shoot, (0.74)-1.48$2.6 \mathrm{~mm}$ long, 0.37-0.74 $\mathrm{mm}$ wide; dorsal margin straight, recurved, without teeth, not decurrent; ventral margin recurved, without teeth, narrowly decurrent. Apex of leaves with 2-4 (-6) unequal curved teeth, the lateral teeth smaller with 2-8 cells at their bases. Lamina cells $35-59 \mu \mathrm{m}$ in diam., $14 \mu \mathrm{m}$ thick with bulging trigones; marginal cells elongated parallel to the margin 35-47 $\mu \mathrm{m}$ long, $19 \mu \mathrm{m}$ wide. Oil bodies ellipsoidal, grayish, refringent, 9-13 (-16) per cell, 7-10 $\mu \mathrm{m}$ long, $2-3 \mu \mathrm{m}$ in diam. Rhizoids are borne laterally below the ventral concave insertion of the leaves and basal to aborted perianths. Dioicous. Androecia spindle shaped, sometimes curved, successive between sets of vegetative leaves, or on lateral intercalary branches at $45^{\circ}$ from the stem, with (3) -6-7 pairs of bracts, each with a dorsal ventricose lobule, the ventral lobe 1-2 apiculate, the lateral margins entire. Gynoecia with subfloral innovations below the bracts, which are similar to the leaves but larger. Female plants with aborted perianths appear as having dichotomous branching, due to the subfloral successive uni or bilateral innovations below the bracts. Perianth 2-2.5 mm high, stipitate, cylindrical at the bases, apical portion laterally flattened, but cylindrical when open; the mouth $1.5 \mathrm{~mm}$ wide, entire except for 3 short teeth or apicula on each lip. Capsule 6 stratose, outer cells elongated longitudinally, $14 \mu \mathrm{m}$ thick, with thin hyaline walls and brown radial thickenings; inner cells $7-9 \mu \mathrm{m}$ thick with thin hyaline walls and semiannular thin brown thickenings. Spores brown 16-17 $\mu \mathrm{m}$ in diam. with small baculi. Elaters up to $141 \mu \mathrm{m}$ long, $9 \mu \mathrm{m}$ in diam with 2-3 helicoidal thickenings.

Discussion. The type material of Plagiochila difficilis Stephani 1911, from Chile, Pto. Chacabuco, Halle \& Skottsberg, 29-VI-1908 (UPS, S), consists of a mixture of a) Plagiochila lophocoleoides Mont. (here designated lectotypus nov.) and b) Plagiochila chacabucencis Steph., as stated by Hässel de Menéndez (1983: 97). Stephani (1918:147), probably referred to the same material. Arnell (1961: 396) cited, with this name, plants from Chile, Osorno, but the identity was not confirmed.

As indicated by Hässel de Menéndez (1983: 93) the type specimen of Plagiochila bispinosa var. angustifolia Herzog (in Herzoget al. "1939"1940), from Chile, Puyuhuapi, Schwabe 79 (at JE), contains: a) lectotypus nov. belongs to Plagiochila bispinosa Lindenb. ex Gottsche (now a synonym of $P$. stictaecola Mont.), b) Plagiochila pudetensis

Fig. 1. Plagiochila lophocoleoides Mont. A. Female plant with aborted perianths, dorsal view. B-C. Branches with perianths. D. Leaves. E. Distal portion of leaf. F. Lamina cells. G. Amphigastrium.

A-B, D-G from Argentina, Chubut, Lago Menéndez, circuito Lago Cisnes, G.H.M. 6937. C from Chile, Chiloé, Río Quilan, Villagrán 261. 


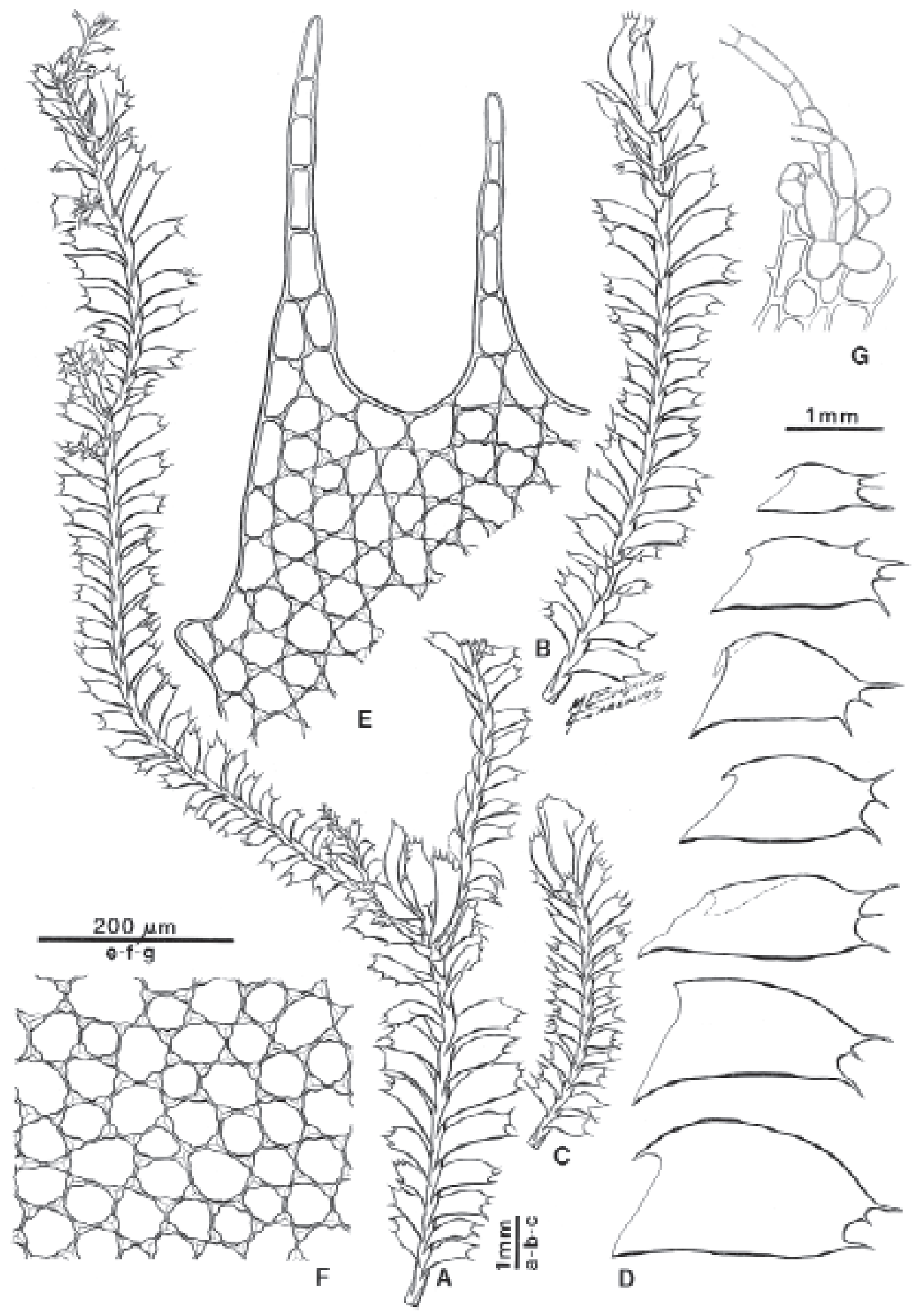


Steph. (now a synonym of $P$. chacabucensis Steph.) and c) Plagiochila lophocoleoides Mont. Hässel de Menéndez (1983: 115) selected the lectotype of Plagiochila pudetensis Steph. (now a synonym of $P$. chacabucensis Steph.).The other three syntypes in the sample, belong to Plagiochila sp., Plagiochila lophocoleoides Mont. and Plagiochila rubescens (Lehm. \& Lindenb.) Lehm. \& Lindenb.

Previous confirmed citations. CHILE: Montagne in Gay (1850: 216) as P. lophocoleoides and P. oligodon; Gottsche et al.(1847: 633) as $P$. oligodon, (1847: 658) as P. lophocoleoides; Dugas (1929: 113) as P. lophocoleoides and P. oligodon; Stephani (1903: 316) as Plagiochila oligodon Mont.; Carl (1931: 130) as Plagiochila oligodon Mont.; Hässel de Menéndez (1983: 110) from Osorno; Herzog (1940: 3, 1954: 32-33), also as $P$. oligodon from Puyehue and Puyuhuapi; Hässel de Menéndez (1983: 110) from Valdivia; Stephani (1911: 32; 1918: 147) from Aysen, locality of the lectotype of Plagiochila difficilis Steph.; from the Chilean Channel Is.: Hässel de Menéndez (1983: 110); Hässel de Menéndez et al. (1984: 50), Greene et al. (1985: 566) and Hässel de Menéndez \& Solari (1985: 328); from Ultima Esperanza. Stephani (1903: 316), Schiffner (1889: 4) as Plagiochila savatieriana Besch. \& Massal. Engel cited the taxon from Peninsula Brunswick (1978: 210) as Plagiochila oligodon Mont. Hässel de Menéndez et al. (1984: 50); Greene et al. (1985: 571) and Hässel de Menéndez \& Solari (1985: 328) reported the species from Magallanes.

Other citations. Further reports of Plagiochila lophocoleoides Mont. by Stephani (1911: 32) from Chiloé and Atalaya I., (1906: 313) from Fretum Magellanicum and Tierra del Fuego, by Reimers (1926: 33) from Panguipulli, by Carl (1931: 130) from Chile; and by Herzog (1960: 186) from Lago Pillaifa, have not been confirmed. Other reports of Plagiochila oligodon by Stephani (1900: 30) and Kühnemann (1936: 95, 1949: 348) from Argentina, Río Negro, by Stephani (1906: 316) from Fretum Magellanicum, by Stephani (1911: 33) from Chile, Chiloé and Grant I., have not been confirmed by examination of the original specimens, but the identity of the species was established on the basis of other specimens examined. Carl (1931: 130) cited P. oligodon from Chile australis. Reports by Buch (1934: 2) from Chile, by Herzog (1938: 10) from Valdivia and (1942: 708) from Juan Fernández Is. and Chiloé, and by S. Arnell (1957: 6) from Juan Fernández Is., have not been confirmed.

Specimens examined. CHILE. N of Valdivia, Fundo San Martin G.H.M. 11009. Puyehue, Río Pascua, Schwabe 9/a (f, c. caps.); Puyehue G.H.M. 10869. Chiloé, I. Grande, Río Quilan, Villagrán 261 (f); Parque Nacional Chiloé, tepual G.H.M. 13439, 13452 (m, f, c. caps.), 13463; Yaldad, G.H.M. 11618; Altui, G.H.M. s. n.; Detico, G.H.M. 13163 (m, f); 13327, 13396 (m, f); 13398 (f, c. caps); I. Quilan, SNE, Villagrán 56 (m). I. Refugio, Villagrán (m). I. Dolores, Villagrán 179 (m). I. Redonda, Villagrán 227. I. Surgidero, Villagrán 134-p. p. Archipiélago Guaitecas, Melinca, Halle 257 (f) (BM as P. oligodon). El Amarillo, G.H.M. 11249 (f, c. caps.), 11254; 11901 (m); 11310 (f, c. per.); id. Drehwald 716 (herb. Drehwald). Carretera Austral, camino de Puyuhuapi a Chaitén, G.H.M. \& Rubies 12863; id. a $67 \mathrm{Km}$. al S de Chaitén G.H.M. \& M. Rubies 13242, 12256; id. al pié del Ventisquero Colgante, G.H.M. \& M. Rubies 12784 (f, c. caps.). Parque Nacional Queulat, sendero de la cascada, G.H.M. \& M. Rubies 12580; 12590 (m); 12707 (m, f); 13348; 12643 (f, c. caps.). Aysen, Pto. Chacabuco, Lago Riesco, Drehwald $547(\mathrm{~m}), 552(\mathrm{~m}) ; 579 ; 600$ (herb. Drehwald); Pto. Chacabuco, Valle Verde, Drehwald 627a (herb. Drehwald). Pto. Cárdenas, Quelle Agua Mineral, Drehwald 778 (m) (herb. Drehwald). Camino de Coyhaique a Aysen, cascada Velo de la Novia, G.H.M. \& M. Rubies 12278 (f, c. caps.); id. Cascada de la Virgen, G.H.M. $\&$ M. Rubies 12340; 12377 (f). Camino de Aysen a Lago Riesco, cascada, G.H.M. \& M. Rubies 12423 (m); 12447 (f, c. caps.). Camino a Bahía Exploradores, G.H.M. \& M. Rubies 11755, 12982 (f). I. Piazzi, Caleta Ocasión, G.H.M., TBPA-B 1091c. I. Rennel, G.H.M., TBPA-B 1394d.; id. CH 197-33, 143-30, 143-18 Eskuche (CTESN). I. Vidal Gormaz. G.H.M., TBPA-B 1538; 1618. Seno Ultima Esperanza, Pto. Bella Vista, Cerro Morro, Schiavone, TBPA-B 2207b; Seno Ultima Esperanza, Pto. Toro, al pié del Cerro Balmaceda, Schiavone, TBPA-B 2574, 2775, 2899, 3047. Magallanes, E shore of Pto. Bueno, Engel 5616E, (MSC 107327 as P. filipendula). E side of S. Nicolás, Engel 63903 (MSC 107445 as P. filipendula); ARGENTINA. Río Negro, Brazo Blest, Los Cántaros, Drehwald 858 (herb Drehwald); Pto Blest, camino al Lago Frías, C. Donterberg \& G.H.M. 1801 (BA 22928); id. G.H.M. 9411, 9417. Lago Frías, Pto. Alegre, G.H.M. 10122, Chubut, Parque Nacional

Fig. 2. Plagiochila lophocoleoides Mont. H. Male plant with androecia, dorsal view. I. Perigonial bracts. J-K. Perianths. L. Teeth of perianth mouth. M. Ventral view of stem with leaves and rhizoids under the leaves. N. Transverse section of stem. H-I from Schwabe 41; J from Chile, Guaitecas I. Melinca, Halle 257 (BM), K-N Argentina, Chubut, Lago Menéndez, circuito Lago Cisnes, G.H.M. 6937 (BA) 
Hässel de Menéndez: Andinopatagonian species of Plagiochila

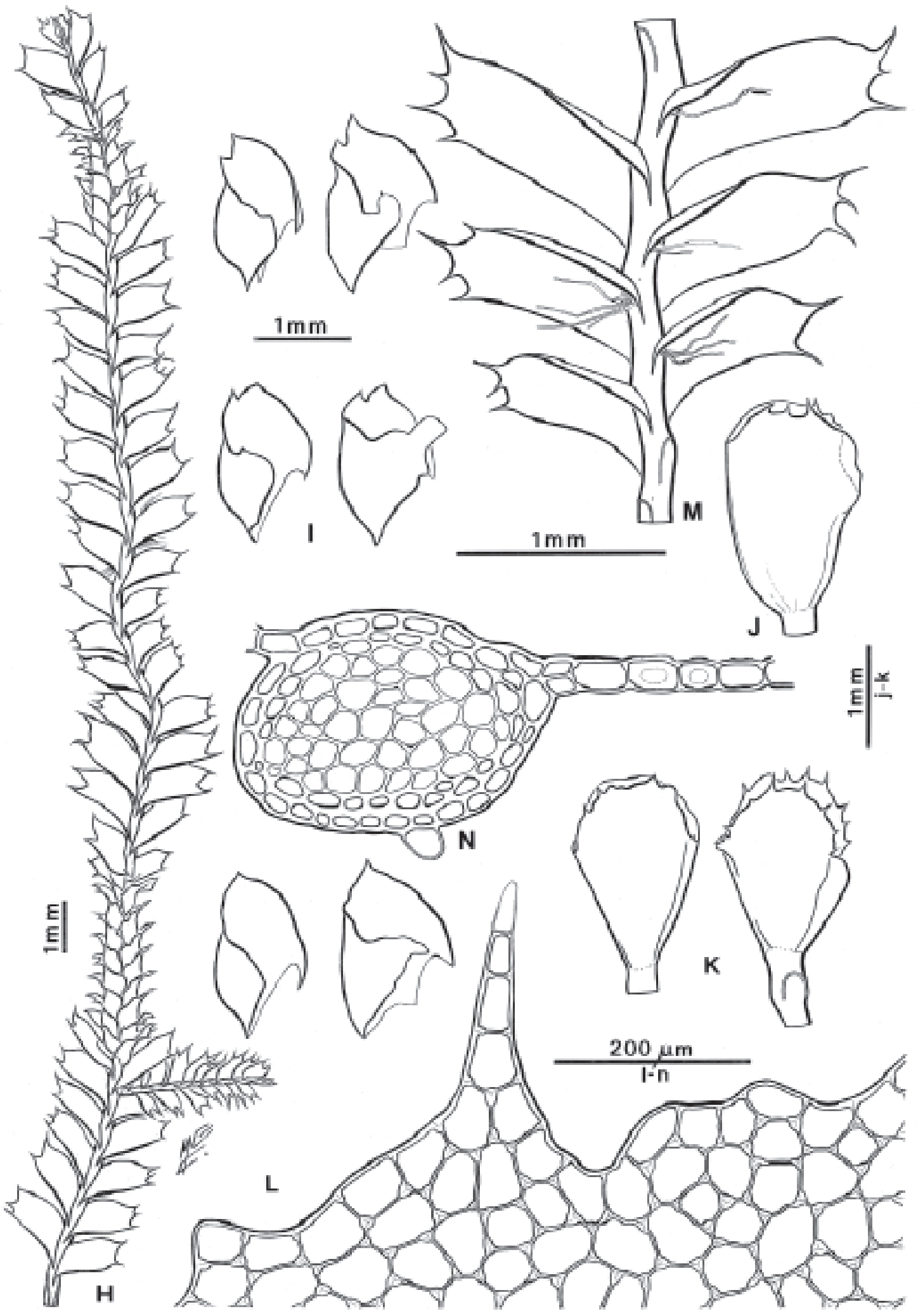


Los Alerces, Lago Menéndez, Alerzal del W, Kühnemann (BA 5589a); Lago Menéndez, Eskuche 1023 (CTESN); id. circuito Lago Cisnes, G.H.M. $6473(\mathrm{~m}) ; 6475 \mathrm{~b} ; 6823 ; 6853,6858 ; 6866$; 6937 (m, f), 6981; id. frente a Lago Cisnes, G.H.M. 11114. Cerro Torrecillas, G.H.M. 7706, 7538; Futalaufquen, Cascada del Cristo G.H.M. 7747, 7800; Lago Futalaufquen, Kühnemann (BA 15578); Río Navarro, Kühnemann (BA 5646). Tierra del Fuego, Bahía Buen Suceso, G.H.M. 3794. I. de los Estados, Bahía Liberty, G. H. M. 4440, 4445a, 4467 (m). G.H.M. (BA); Villagrán (herb. Villagrán). ( $m=$ male,$f=$ female, c. caps. = cum capsula $=$ with sporophyte).

Ecology and distribution. Plagiochila lophocoleoides is present in Chile from Osorno to Peninsula Brunswick, and in Argentina from Río Negro to Tierra del Fuego. It forms loose to compact nearly flat carpets on rotten logs, wet rocks, stream banks, soil under tree ferns, wet rocks at the shore and also grows on Amomyrtus luma, Nothofagus betuloides, $N$. dombeyii, on Fuchsia sp. with Apometzgeria frontipilis, Archeophylla pungens, Arctoscyphus fuegiensis, Chiloscyphus inflexispinus, C. muricatus, C. obvolutus, C. striatellus, C. subviridis, Gackstroemia schwabei, Leiomitra elegans, Metzgeria sp., Plagiochila angulata, $P$. chacabucensis, $P$. chiloensis, $P$. chonotica, $P$. dusenii, $P$. flava, $P$. flexicaulis, $P$. longiflora, $P$. subpectinata, $P$. stictaecola, Radula sp., Triandrophyllum subtrifidum, in Chiloé epiphyllous on Griselinia racemosa, Guevina avellana, Myrceugenia planipes.

\section{Sectio Flexicaules Carl, Ann. Bryol. Suppl. 2: 127, 1931.}

Lectotype species.Plagiochila flexicaulis Mont. (= P. filipendula Steph.).

Plants delicate, wiry, pale green; branching irregular through lateral intercalary branches and subfloral innovations, to $12 \mathrm{~cm}$ long, with distant small obcuneate truncate leaves dentate at tips. The lamina consists of small isodiametric cells 9-15 $\mu \mathrm{m}$ in diam. with uniformly thickened walls. The perianth is stipitate, cylindrical, the mouth laterally flattened, expanded and dentate.

Discussion. Carl (l. c.) pointed out the characters that define this "typus" as he called the section: the delicate, variously branched plants with small distant oval elongated leaves, the oblique apical portion of the cuneate leaves, and the small cells of the apical portion of the leaves. At that time specimens were only known with juvenile perianths. He included in this group Plagiochila fasciata Steph. (although describing it to have an ovoid perianth with a constricted mouth), $P$. filipendula Steph. and P. flexicaulis Mont.

As indicated below $P$. filipendula was considered a synonym of $P$. flexicaulis by the author (1983:102-103) and P. fasciata Steph. was included by the author (1983:102, 104, as P. gayana Mont., 2006: 110) in the synonymy of $P$. heterodonta (Hook. f. \& Taylor) Hook. f. \& Taylor in Gottsche $\&$ al., based on one of the syntypes from Juan Fernández Is.

Plagiochila flexicaulis Mont. in Gottsche \& al., Syn. Hep.: 629, 1847.

(Figs. 3-4, 6 B, 7 E-F)

Typus. "inter muscos in Chili australi, Gay" (PC! holotypus).

$=$ P. filipendula Steph., Kongl. Svenska Vetensk.-Akad. Handl. 46(9): 30, fig. 12h, 1911.

Typus. Chiloé ad flumen Pudeto, in loco San Antonio dicto, Halle \& Skottsberg 546 (UPS!, G 20850!, isotypi).

Illustrations. Dugas (1929) fig. 46; Stephani (1911) fig. 12 b, typus of Plagiochila filipendula Steph.; Carl (1931) fig. 2 (17), 12b.

Description. Plants pale green, dull, $5-12 \mathrm{~cm}$ long, arising from creeping system distributed in the bryophyte carpet, with irregular lateral intercalary branching. Stem cylindrical yellowish green, $120-240 \mu \mathrm{m}$ (14-15 cells) in diam., cortex 2 stratose, the cortical cells $6-9 \mu \mathrm{m}$ in diam. with very thickened walls, the medulla cells $18-45 \mu \mathrm{m}$ in diam., with hyaline thickened walls. Leaves obcuneate, distant, when dry longitudinally convolute, $0.60-1.20 \mathrm{~mm}$ long (increasing in size acroscopically when gynoecia are present), 0.30 $0.80 \mathrm{~mm}$ wide in the sub apical portion, $90-270$ $\mu \mathrm{m}$ wide at the base; insertion short oblique, dorsally decurrent, with short ventral inverted $U$ shaped, not decurrent; the lamina expanded at $45^{\circ}$ from stem, cnemis short also at $45^{\circ}$ with stem; dorsal margin straight, slightly recurved, without teeth, except for 1-several small teeth directed towards the tip of the leaf; apex of leaves truncate, straight to concave, limited by two larger teeth (the dorsal tooth larger), with several smaller intermediate teeth, ventral margin with 4-6 (-10) dissimilar teeth directed towards the apex of leaf. Lamina cells mainly isodiametric,

Fig. 3. Plagiochila flexicaulis Mont. A. Female plant with aborted perianths, dorsal view. B. Leaves. C. Distal portion of leaf. D. Lamina cells. E. Immature perianth. F. Teeth of perianth mouth. G. Amphigastrium. A-G Chile, Chiloé, ad flumen Pudeto in loco San Antonio dicto, Halle \& Skottsberg (UPS as P. filipendula Steph.). 


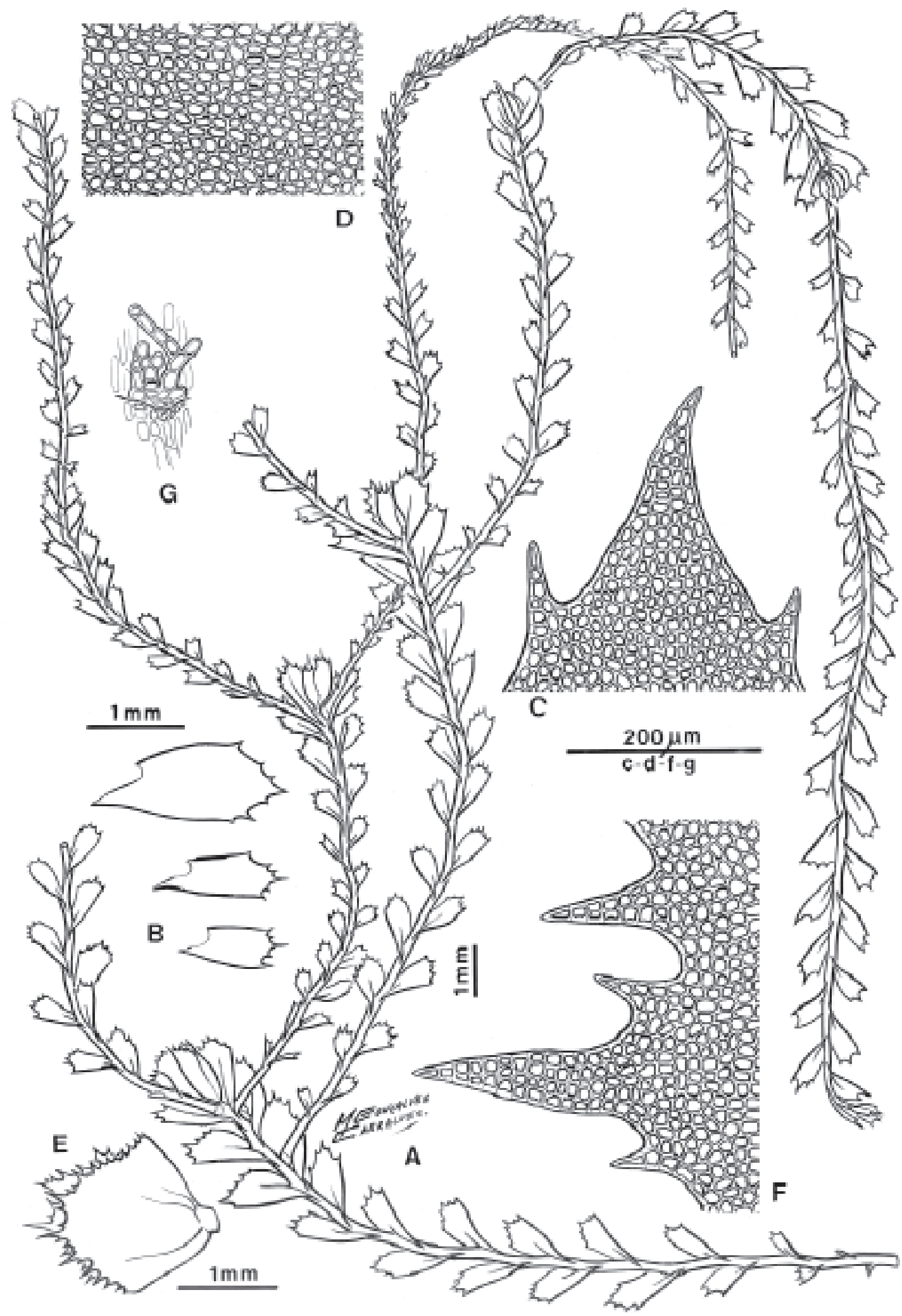


9-15 $\mu \mathrm{m}$ in diam., $15 \mu \mathrm{m}$ thick with uniformly thickened walls; at the base of leaves the cells are elongated longitudinally, $30-42 \mu \mathrm{m}$ long, the thickened walls have also intermediate nodular thickenings, the marginal cells are elongated parallel to the margin where the cuticle is $3 \mu \mathrm{m}$ thick. Oil bodies ovoid to fusiform, 5-7 $\mu \mathrm{m}$ long, 2-2.5 $\mu \mathrm{m}$ wide, $4-8$ per cell. Amphigastria small, triangular to filamentous. Dioicous. Androecia fusiform slightly curved, intercalary between normal leaves, infrequently successive, $60-100 \mu \mathrm{m}$ wide, with 6-9 pairs of ventricose close imbricate bracts, each with 2 distal teeth and the ventral margin with 4 acute 1 cell long teeth. Gynoecia on main shoot or at tips of branches, frequently aborted and with innovations on both sides under the bracts, and repeating this structure several times on the same plant. Bracts similar to the distal leaves, obcuneate with a narrow base, to $1.83 \mathrm{~mm}$ long and to $1.00 \mathrm{~mm}$ wide with about 16 or more dissimilar triangular teeth. Perianth stipitate (not illustrated), $3.5-4.0 \mathrm{~mm}$ high, cylindrical, above laterally flattened, the cells similar to the leaf cells, more elongated and with intermediate nodular thickenings on the cell walls; the mouth expanded to $2.5 \mathrm{~mm}$ wide, in the middle with 2 main triangular teeth with 10 or more cells at their base and short teeth on the remaining margin. Seta exceeding the perianth. Capsule 5-6 stratose, the outer cells with hyaline walls but with red brown radial thickenings; the inner cells with red brown semiannular thickenings. Spores red brown $15 \mu \mathrm{m}$ in diam. covered with small baculi. Elaters curved 90-109 $\mu \mathrm{m}$ long and $12 \mu \mathrm{m}$ wide with $1-2$ helicoidal thickenings.

Previous confirmed citations. CHILE: Montagne (1850: 213); Dugas (1929: 74); Stephani (1903: 310), Hässel de Menéndez \& Solari (1985: 327) from Valdivia; Stephani (1918: 155) and Oberdorfer (1960: 107) from Chiloé as Plagiochila filipendula; Hässel de Menéndez (1983: 103) from Chiloé; Massalongo (1928: 234, 1906: 9) from Aysen, Poyo-huapi, as Plagiochila obcuneata Steph.; Hässel de Menéndez et al. (1984: 50) and Hässel de Menéndez \& Solari (1985: 50) from Ultima Esperanza. The citations of Plagiochila flexicaulis Mont., by Stephani (1906: 130) from Chile Australis, Patagonia Occidentalis, and by Herzog (1954: 32) from Puyuhuapi and Ofqui, have not been confirmed. The author reports a new record of the species from Osorno.
Specimens examined. CHILE: Juan Fernández Is., Masafuera, Trail to Portezuelo de Villagra, 1400-1800 ft., Hatcher \& Engel 71 (f, per. abort.) (MSC); id. Hatcher \& Engel 457 (MSC 108328 as P. filipendula). Masatierra, Summit of El Yunque, Kunkel 927/3 (H); Valle Anson, forest above Plazoleta del Yunque, 40-500 m, C. \& I., Skottsberg (UPS as P. fuscobrunnea). Temuco, Fr. Claude Joseph 38, 39 (m), 199 (US as P. hyadesiana). Puyehue, sobre ladera de corte de camino, G.H.M. 10917. Valdivia, Cuncu-Panguipulli, Hollermayer (f) (JE); id. prope Bella Vista, in valle fl. Trumao, Lechler, Pl. Chil. de Hohenacker (f) (M); id. Lago Riñihue in Aextoxicum forest, Santesson (S as P. filipendula); id. Lechler (US); id. Fundo San Martin. G.H.M. 11002 (m), 11023 (f), 11073 (m), 11074 (m, f, c. caps.), 11097, 11100 (m). Cordillera Pelada, camino del Mirador, Eskuche 369 (CTSN); Patag. occid. Guaitecas Is., Kustbyn, Dusén (m) (S, UPS, as P. filipendula). Chiloé, Halbinsel Lacuy, Quensel (UPS as $P$. obcuneata); Chiloé, Lechler (BM); id. Villagrán 292 p. p., 293 (m), 295 (m, f); Cordillera. Piuchué, I. Trans. 94, Trans. I, 4 Quilan SE, Villagrán (m); Detico, G.H.M. 13394 (f, c. caps). Carretera Austral, Puyuhuapi a Chaitén, Lago Risso Patrón, G.H.M. \& M. Rubies 12857; id. Puyuhuapi a Chaitén, pasando La Junta, G.H.M. \& M. Rubies 12961 (m); id. junto al muelle de Chaitén, G.H.M. \& M. Rubies 13220. Poyo-huapi, Spegazzini, 14, II-1898 (VER as P. obcuneata). Prov. Aysen, Pto. Aysen, Drehwald 521 (herb. Drehwald); id. Lago Riesco (zwischen Pto. Chacabuco und Pto. Aysen), Drehwald 579, 595 (herb. Drehwald). Patag. occid., Pto. Chacabuco, Halle 293 (m) (UPS as $P$. rufescens). Chile, isola San Pietro, Dusén III-1897 (US). I. Piazzi, G.H.M., TBPA-B 1063, 1091b, 1104d. I. Rennel, G.H.M., TBPA-B 1283b, 1325d (f, c. caps.). Chile australis, ad Quele, Dusén XI1896 (m). (M)

Ecology and distribution. Plagiochila flexicaulis is known from Chile, the Juan Fernández Is., Guaitecas Is., Chiloé Archipiélago and the Channel Is. On the continent it extends from Osorno to Aysen. In the northern localities it inhabits living trees, associated to Lepicolea sp., Metzgeria sp., Plagiochila chiloensis, $P$. dusenii, P. flava, P. lophocoleoides, . rubescens, P. stictaecola, Porella sp., Tylimanthus kunkelii, and various species of Lejeuneaceae. In the Chan-

Fig. 4. Plagiochila flexicaulis Mont. H. Male plant with androecia, dorsal view. I. Perigonial bracts. J. Ventral view of stem with leaves. K. Transverse section of stem. H-K from Chile, Guaitecas Is., Dusén (UPS as P. filipendula Steph.). 


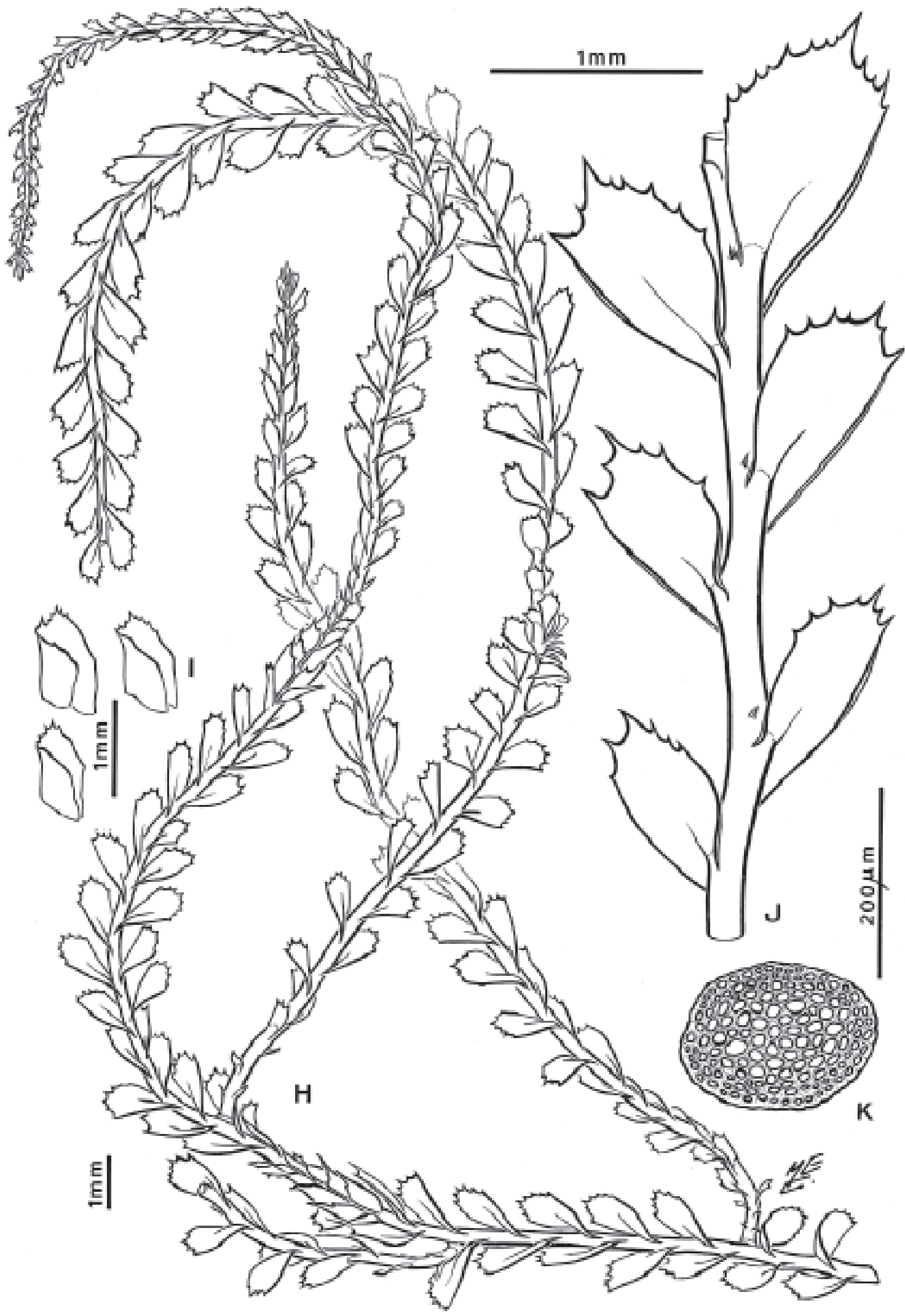


nel Islands it was found in wooded shaded humid gorge at $100 \mathrm{~m}$, on wet rocks by waterfall and on wet rocks above lake, associated with Herbertus runcinatus, Lepicolea rigida, Plagiochila acanthocaulis, P. dura, P. obovata, P. subpectinata, Riccardia spinulifera, Tylimanthus tenellus, etc.

\section{Sectio Longiflorae Carl, Ann. Bryol. Suppl. 2:130. 1931.}

Plants delicate, short, arborescent; the lamina cells of leaves with trigones and thickened walls; the perianth long cylindrical laterally compressed and its opening has nearly straight long and thin bristle like teeth.

Type species. Plagiochila longiflora Mont. ex Gottsche \& al.

This Section includes only one species, because the second name cited by Carl (l. c.), P. ariquensis Steph., was considered by Hässel de Menéndez (1983: 92, 109) a synonym of $P$. longiflora Mont.

Plagiochila longiflora Mont. ex Gottsche \& al., Syn. Hep. 651, 1847.

(Figs. 5, 6 C, 7 C-D)

Typus. Habitat in Chile, in cortice arborum, Gay (PC! holotypus)

= Plagiochila ariquensis Steph., Spec. Hep. 2: 473, 1904.

Typus. Chile, Arique, Lechler (G! 20844 lectotypus)

(Hässel de Menéndez 1983).

= Plagiochila hepaticola Steph., Kongl. Svenska

Vetensk.-Akad. Handl. 46 (9): 30, 1911, n. inval. (non

P. hepaticola Steph., Spec. Hep. 6:165, 1918)

Original material: Chile, Chiloé ad ostium Río Pudeto,

ad pontem, Halle \& Skottsberg, 16-VII-1908 (UPS!).

= Plagiochila hepaticola Steph., Spec. Hep. 6: 165, 1918.

Typus. Chile, Valdivia, Lechler (G! 1575 holotypus).

= Plagiochila ofquiensis S. W. Arnell \& Herzog in Arnell

S., Svensk. Bot. Tidskr. 52: 549, fig. 1, 1959 “1958”.

Typus. Chile, Westpatagonien, Istmo de Ofqui, Grosse 156, 1939-1940 (JE! holotypus).

Illustrations. Arnell S. (1958) fig. 1, typus of Plagiochila ofquiensis S. W. Arnell \& Herzog; Dugas (1929) fig. 122.

Description. Plants delicate arborescent to $5 \mathrm{~cm}$ long, 2.5-3.0 $\mathrm{mm}$ wide between leaf apices along shoot; attached to the bryophyte carpet by an irregular creeping system, irregularly branched, mainly by subfloral lateral intercalary innovations, microphyllous branches present near the base of plants. Stem straight cylindrical dorsiventrally flattened, orange coloured, $270 \mu \mathrm{m}$ (1314 cells) in diam., cortex 3 stratose, the cells 15 $\mu \mathrm{m}$ in diam., the thickened walls orange coloured, medulla cells $15-30 \mu \mathrm{m}$ in diam. with thin hyaline walls. Leaves ovate, the apex rounded or truncate, 0.92-1.52 mm long, 0.76-0.92 mm wide, insertion oblique, dorsally not decurrent, ventrally with inverted U arch, short decurrent, cnemis short oblique; the lamina slightly ventrally oriented; dorsal margin straight, recurved, with 1-2 short distal teeth directed towards the tip of leaf; ventral margin with 11-15 straight to curved, unequal, distant teeth, these at their base 1-2 cells wide, 1-4 (-5) cells long; the teeth cells 18-24 $\mu \mathrm{m}$ long, the distal cell longer $(48-66 \mu \mathrm{m})$ and attenuate, sometimes curved or collapsed. Lamina cells 30 $45 \mu \mathrm{m}$ long, 24-30 $\mu \mathrm{m}$ wide, $30 \mu \mathrm{m}$ thick, with conspicuous trigones connected close to the external surfaces as thickened cell walls, the cuticle 6-9 $\mu \mathrm{m}$ thick. Oil bodies sub spherical 4-7 $\mu \mathrm{m}$ in diam. greyish, with coarse granules, (6)-8-10 per cell. Amphigastria very small and delicate. Dioicous. Male plants less branched. Androecia successive and intercalary on shoot with vegetative leaves, spindle shaped, narrower than the vegetative leafy shoot, $0.92-0.48 \mathrm{~mm}$ wide with 3 6 pairs of contiguous to imbricate bracts; lower bracts $1.06 \mathrm{~mm}$ long, distal bracts $0.76 \mathrm{~mm}$ long, the dorsal lobe irregular to involute, the ventral portion with short teeth similar to vegetative leaves, the apex squarrose. Several gynoecia on shoot, due to successive unilateral (less frequently bilateral) subfloral innovations (under the second bract) at irregular distances. Bracts in 2 pairs, each to $2.74 \mathrm{~mm}$ long, $1.22 \mathrm{~mm}$ wide, the cells similar to leaf cells but more elongated, the teeth on both margins and more numerous and curved. Perianth 4.5$5.0 \mathrm{~mm}$ long, and $2.2 \mathrm{~mm}$ wide, cylindrical at base, laterally flattened, the tip curved to one side. Perianth cells similar to the leaf cells. The opening with 2 rounded lips with bristle like, straight or curved, unequal teeth, being the middle teeth the longest, at their base 1-3 cells wide, and to 13 cells long, the lateral ones diminishing in length to only 1 cell long. Seta 16 cells in diam., exceeding the perianth. Capsule brown, pluristratose. Spores brown, $20 \mu \mathrm{m}$ in diam. baculate. Elaters to $190 \mu \mathrm{m}$ long with 2 helicoidal thickenings.

Discussion. Having studied the composition of the epiphytic bryophyte carpet on many trees

Fig. 5. Plagiochila longiflora Mont. ex Gottsche. A. Female plant with perianths and innovations, dorsal view. B. Male plant with androecia, dorsal view. C. Branch with leaves, ventral view. D. Leaves. E. Perigonial bracts. F. Perianth bracts. G. Perianth. H. Teeth of perianth mouth. I. Margin and lamina cells at leaf base. J. Lamina cells. K. Transverse section of leaf. L. Transverse section of stem. M. Amphigastrium. A-M from Argentina, Chubut, Lago Menéndez, circuito al Lago Cisnes, G.H.M. 7183. 


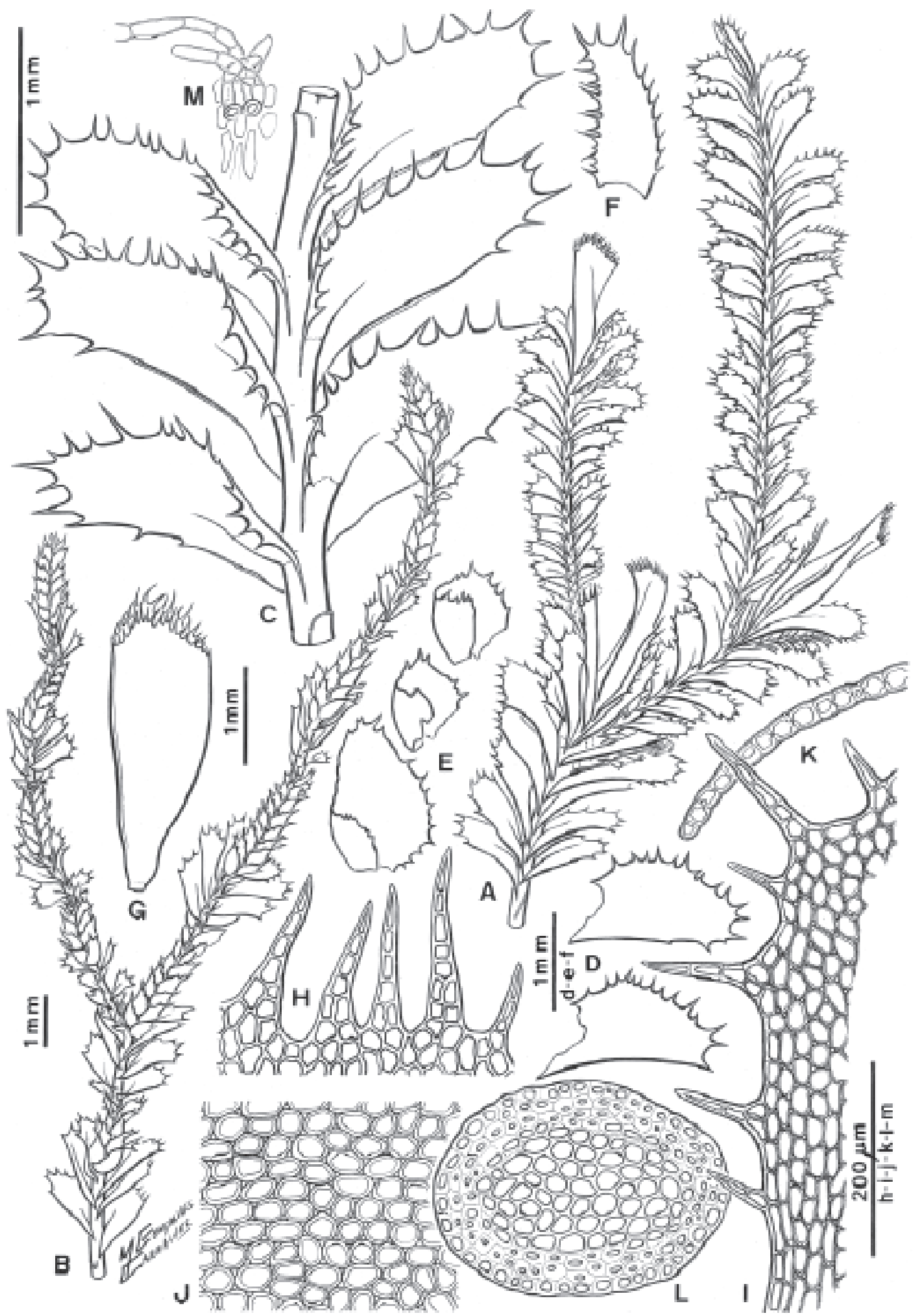




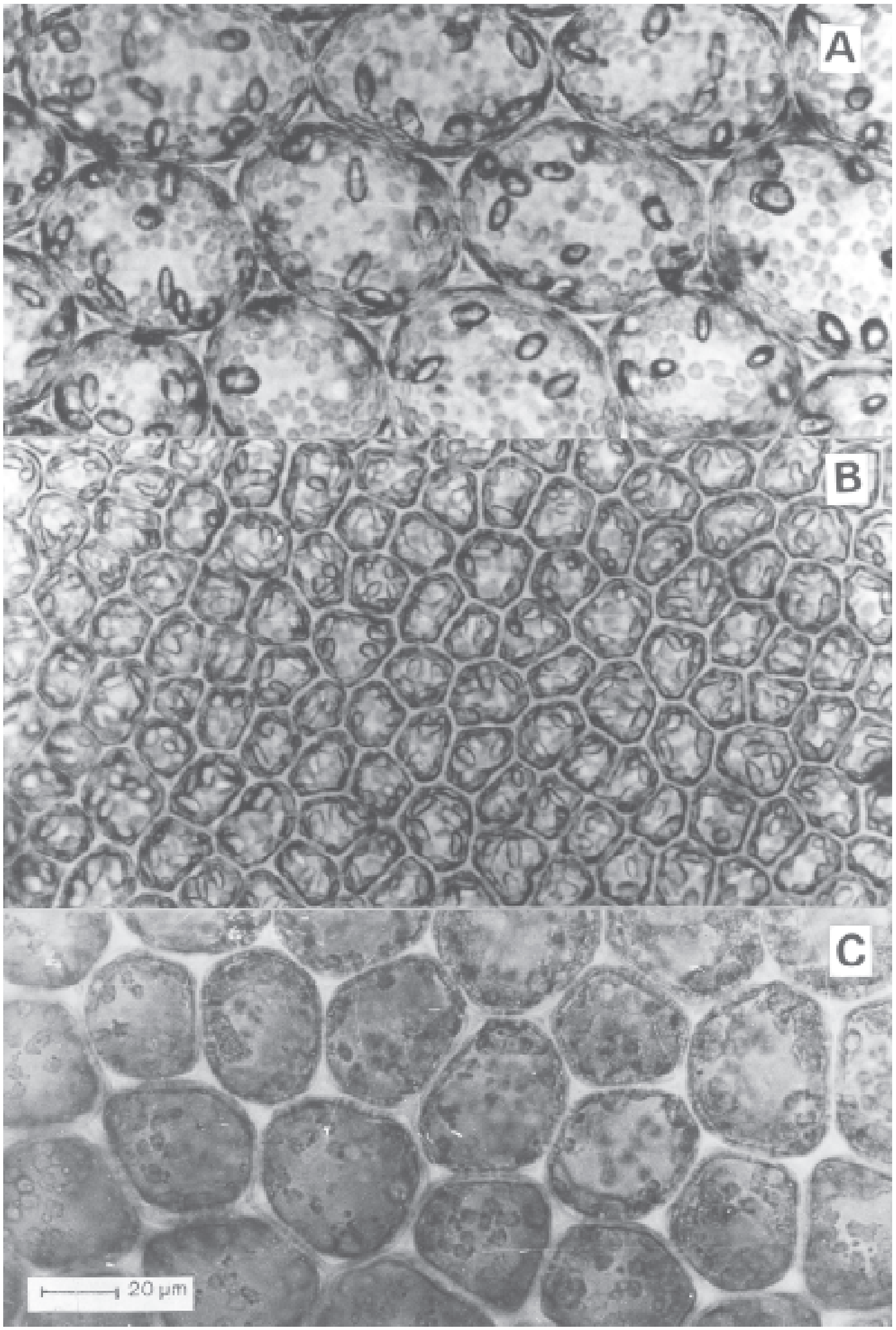

Fig. 6 Lamina cells. A. Plagiochila lophocoleoides Mont., Puyehue, G.H.M. 10869. B. P. flexicaulis Mont., Nilque, G.H.M. 10986. C. P. longiflora Mont. ex Gottsche, Lago Menéndez, G.H.M. 7183. 


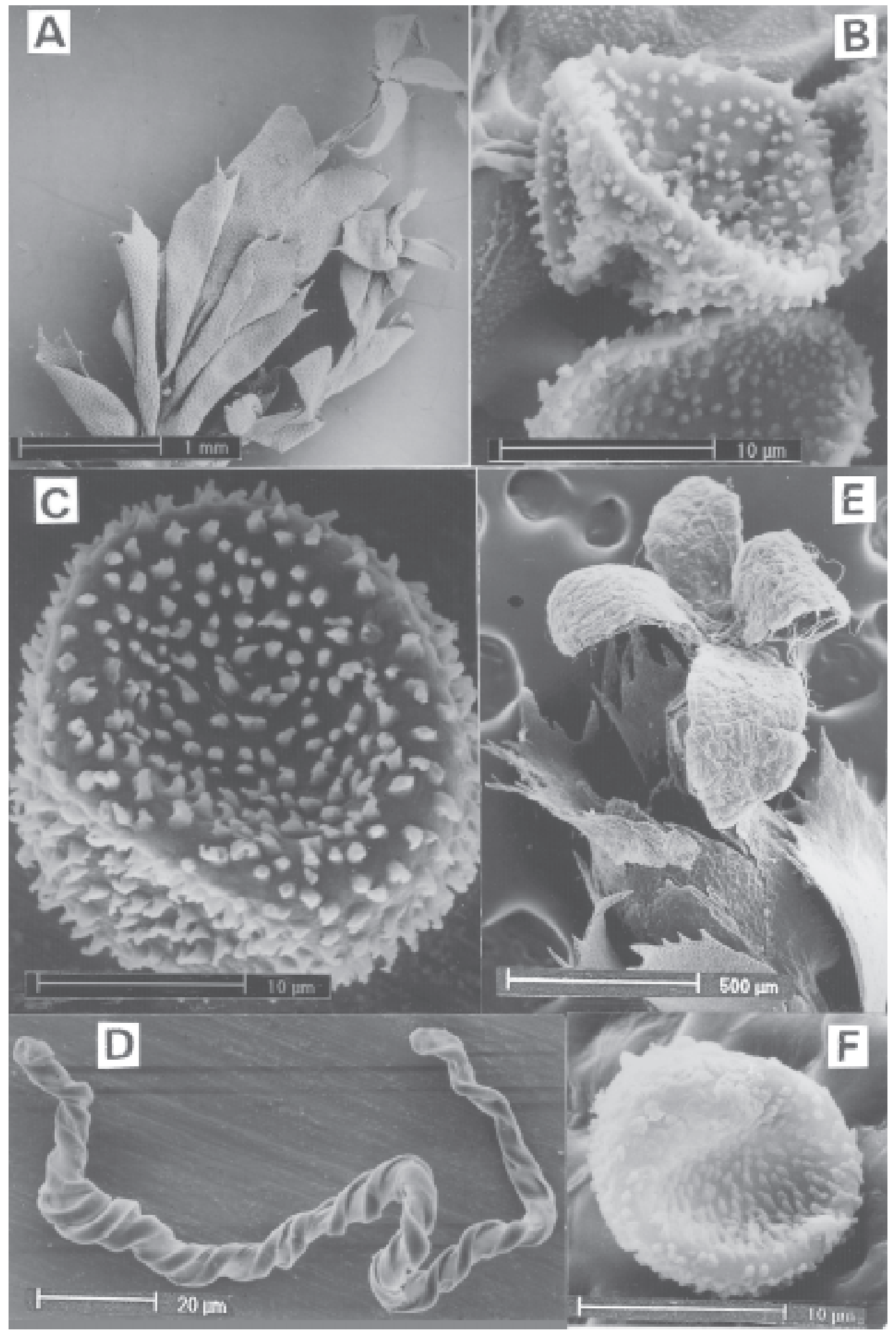

Fig. 7 Spores and elaters. Plagiochila lophocoleoides Mont. A.Perianth and capsule. B. Spores. P. longiflora Mont. ex Gott. C. Spore. D. Elater. P. flexicaulis Mont. E. Perianth and capsule. F. Spore. A-B. Chiloé, Deticos, G.H.M. 13396. C-D. Lago Menéndez, circuito al Lago Cisnes, G.H.M. 6079. E-F. Chiloé, Deticos G.H.M. 13394. 
(see below) in the evergreen forests of Argentina, it has become known that this taxon is most frequent, and although dioicous, most commonly both male and female plants are growing together and present developed sporophytes. One character that distinguishes this species, is that their frequently unilateral innovations arise below the second pair of bracts.

Previous citations. Plagiochila longiflora was cited from Chile by Montagne (1850: 220) and Hässel de Menéndez (1983: 109); from Valdivia by Hässel de Menéndez (1983: 109) and from Chiloé by Oberdorfer (1960: 95), Hässel de Menéndez (1983: 109) and from Istmo de Ofqui by Hässel de Menéndez (1983: 109).

Other citations. Plagiochila longiflora Mont. was reported by Stephani (1900: 29) and Kühnemann (1936: 94, 1949: 348); from Argentina, Río Negro; by Stephani (1911: 32) from Chile, Chiloé; by Reimers (1926: 36) from Panguipulli, by Carl (1931: 131) from Valdivia, by Herzog (1923: 3) from Valdivia, (1938: 10) from Valdivia, (1940: 4) from Argentina, Río Negro, (1954: 34) from Chile, Magdalena I. and (1960: 184) from HuitrapulliAleucapi; these citation have not been confirmed because the specimens were not available for their studies. Plagiochila ariquensis Steph. was also cited from Chile, Valdivia by Carl (1931: 131) and from Puyuhuapi by Herzog in Herzog et al . (1939: $2)$; these specimens have not been analyzed recently.

Specimens examined. CHILE, Valdivia, Herzog (f) (M); id. Corral, Lechler (f, c. caps.) (W 355354 as Plagiochila gayana) (US); id. Corral, Quitaluto, Hosseus 679 A (m) (M), id. Fundo San Martin, G.H.M. 11063, 11067 (m), 11070 (m), 11071 (f), 11086 (f); El Amarillo, G.H.M. 11259, 11270; Parque Nacional Queulat, G.H.M. \& M. Rubies 12682; camino de Puyuhuapi a Chaitén, G.H.M. \& M. Rubies 12967; Aysen, Lago Riesco, G.H.M. \& M. Rubies 12427; Chiloé, Yaldad, G.H.M. 11623 b (f, c. caps.). I. Refugio, Villagrán 112 (herb. Villagrán). ARGENTINA. Neuquén, Villa La Angostura camino a Chile, G.H.M. \& S. Solari 8631. Río Negro, Pto. Blest, 6334, 6342 (f), 6359, 6360, $6362,6417,6460$ (m), 6615 (f, c. caps.), $6625 b$ (f, c. caps.), $6806 \mathrm{~b}$ (f, c. caps.), 6868 (m, f), 8029 (f, c. caps.), 8031 (f), 8039,8043 (f); Pto. Blest camino a Los Cántaros, antes de llegar al Río Blest, G.H.M. 8827 (f), 8837 (m), 8855, 8904 (f), 9065 (f); Pto Blest, camino a Los Cántaros, pasando el Río Blest, G.H.M. 10481 (m, f); Pto. Blest, camino al Lago Frías, turbera, 9354 (f, c. caps.), 9214 (m), id. en el bosque, G.H.M. 9375 (f), 9385 (f, c. caps.), 9400, 9430, 9485 (m, f), 9507 (f, c. caps.). Chubut, Parque Nacional Los Alerces, Lago Menéndez, G.H.M. 7053 (f, c. caps.), 7069 (m, f, c. caps.), 7078 (f, c. caps.), 7086 (m), 7097 (m), 7106, 7107, 7113 (f, c. caps.), 7121 (m. f), 7138 (m, f), 7182 (m), 7587.

Ecology and distribution. Plagiochila longiflora was first known from Chile near Valdivia and it is now confirmed on the basis of the authors collections that the species extends as far south in Chile as the Aysen area, and Chiloé. It is in general an epiphyte growing in dense carpet with mosses, with Chiloscyphus inflexispinus, Leiomitra elegans, Metzgeria species, Plagiochila chonotica, P. rufescens, Radula species, etc. Infrequently it was found on the ground in Chiloé. The species was located in Argentina in the National Parks Nahuel Huapi and Los Alerces, where it dwells almost on every trunk: Nothofagus dombeyii, Azara sp., Amomyrtus luma, Dasyphyllum sp., Podocarpus nubigena, Saxegothea conspicua, with mosses and Chiloscyphus cucullistipulus, C. gayanus, Lejeuneaceae species, Metzgeria species, Leiomitra elegans, Plagiochila dusenii, $P$. heterodonta, $P$. stictaecola, etc.

\section{ACKNOWLEDGEMENTS}

I am very grateful to the Curators of following herbaria: BA, BM, CTESN, FI, G, H, JE, M, MSC, PC, S, UPS, US, VER, W for the loan of specimens and I have to express my thanks to Dr. Ulrich Eskuche, Dr. Uwe Drehwald and Prof. Dr. Carolina Villagrán for the supply of specimens related to this study. I thank Mrs. Marta Rubies for her assistance with the literature, the typography of the manuscript and arrangement of the illustrations prepared skillfully by Prof. Matilde Gonçalves-Carralves. The help of Fabián Tricarico and Ángel Fusaro of the Servicio de Microscopía de Barrido of the MACN is also acknowledged. Financial support was received from the CONICET of Argentina.

\section{BIBLIOGRAPHY}

Arnell S. 1957. Hepaticae collected during Dr. and Mrs.

C. Skottsberg's second expedition to the Juan Fernández Islands, Dec. 1954-March 1955. Ark. Bot. II, 4: 1-21.

1961. Some new American species of hepatics. Svensk. Bot. Tidskr. 55(1): 205-210.

Bescherelle E. \& C. Massalongo. 1889. Hepaticae novae americanae-australes. Bull. Mens. Soc. Linn. Paris 1(79): 626-32.

Buch H. 1934. Verzeichnis der von H. Roivainen in Südchile während der Auer'schen Feuerlandexpedition im Jahre 1929 gesammelten PlagiochilaArten. Ann. Bryol. 7: 1-5.

Carl H. 1931. Die Arttypen und die systematische Gliederung der Gattung Plagiochila. Ann. Bryol. Suppl. 2: 1-170 
Dugas M. 1929. Contribution a l'etude du genre "Plagiochila" Dum. Ann. Sci. Nat. Bot. X Serie, 11: 1-199.

Engel J.J. 1978. A taxonomic and phytogeographic study of Brunswick Peninsula (Strait of Magellan) Hepaticae and Anthocerotae. Fieldiana Bot. 41: iviii; 1-319.

Gottsche C.M., J.B.G. Lindenberg \& C.G. Nees ab Esenbeck. 1844-1847. Synopsis Hepaticarum: 1-834. Hamburg.

Greene S.W., G.G. Hässel de Menéndez \& C. Matteri. 1985. La contribución de las Briofitas en la vegetación de la Transecta. In: O Boelcke, D.M. Moore y F.A. Roig. Transecta Botánica de la Patagonia Austral. p 557-591.

Hässel de Menéndez G.G. 1983. Informaciones nomenclaturales sobre las especies del género Plagiochila (Hepaticae) de Argentina y Chile. Bol. Soc. Argent. Bot. 22(1-4): 87-129.

- 2004a. Andinopatagonian species of Plagiochila (Plagiochilaceae, Marchantiophyta). I. Sectio Robustae Carl emend. Hässel and II. Sectio Equitantes Carl emend. Hässel. J. Hattori Bot. Lab. 96: 245-260.

- 2004b. Andinopatagonian species of Plagiochila (Plagiochilaceae, Marchantiophyta) Sectio Obcuneatae Carl. Revista Inst. Nac. Invest. Ci. Nat., Ci. Bot. N.s. 6(2): 197-208.

- 2006. Andinopatagonian species of Plagiochila (Plagiochilaceae, Marchantiophyta). I Sectio Hirtae and II Sectio Angulatae. J. Hattori Bot. Lab. 100: 101-118.

- 2008. Andinopatagonian species of Plagiochila (Plagiochilaceae, Marchantiophyta). Sectio Chilenses Carl. Nova Hedwigia 86(1-2): 169-199.

Hässel de Menéndez G.G., S.W. Greene \& C. Matteri. 1984. The occurrence and distribution of Bryophytes in southern Patagonia between latitude $51^{\circ}$ and $52^{\circ} \mathrm{S}$. J. Hattori Bot. Lab. 55: 45-64.

Hässel de Menéndez G.G. \& S. Solari. 1985. Catálogo de las Hepáticas. In: O. Boelcke, D.M. Moore \& F.M. Roig (eds.) Transecta Botánica de la Patagonia Austral p 299-342.

Herzog T. 1923. Beiträge zur Bryophytenflora Chiles. Hedwigia 64(1-2): 1-18.

- 1938. Contribución al conocimiento de la flora Briofita del Sur de Chile. Parte Sistemática. Arch. Esc. Farm. Fac. Cienc. Méd. Córdoba, Sec. Cient. 7:1-56.

- 1940. Die Moose der Expedition Ljungner nach Patagonien 1932-1934. Ark. Bot. 29(21):1-17.
1942. Die foliosen Lebermoose der Juan FernándezInseln und der Osterinsel. In: C. Skottsberg (Ed.): The Natural History of Juan Fernández and Eastern Island 2(5): 697-752. Uppsala.

- 1954. Zur Bryophytenflora Chiles. Rev. Bryol. Lichénol. 23: 27-99.

Herzog T. 1960. Weitere Beiträge zur Bryophytenflora Chiles. Rev. Bryol. Lichénol. 29: 183-206.

Herzog T., G.H. Schwabe \& E. Schwabe 1939. Zur Bryophytenflora Südchiles. Beih. Bot. Centralbl. Abt. B60: 1-51.

Kühnemann O. 1936. Contribución al catálogo briológico argentino I. Revista Centro Estud. Doct. Ci. Nat. 1(2): 85-97.

- 1949. Catálogo de las Hepáticas Argentinas. Lilloa 19: 319-75.

Massalongo C. 1906. Epatiche della Republica Argentina raccolte dal Prof. C. Spegazzini. Atti. Acad. Sci. Med. Nat. Ferrara : 1-14.

- 1928. Revisio critica Hepaticarum quas in Republica Argentina Prof. C. Spegazzinius legebat, additis (speciebus) novis. Atti Ist. Veneto Sci. 87(2): 215-51.

Montagne C. 1850. Plantes cellulares. II. Hepaticas. In: C. Gay (ed.), Historia Física y Política de Chile. Botánica 7: 202-327.

Oberdorfer E. 1960. Pflanzensoziologische studien in Chile. Ein Vergleich mit Europe. Flora et Vegetatio Mundi II: 1-208.

Reimers H. 1926. Beiträge zur Bryophytenflora Südamerikas. I u. II. Hedwigia 66: 27-78.

Schiffner V. 1889. Lebermoose (Hepaticae), mit Zugrundelerung der von Dr. A.C.M. Gottsche ausgeführten Vorarbeiten. In: A. Engler (ed.), Die Forschungsreise S.M.S. "Gazelle" in Den Jahren 1874 Bis 1877 Unter Dem Kommando Des Kapitäns Zur See Freiherrn Von Schleinitz. 4(Botanik): 48 pp.

Stephani F. 1900. Beiträge zur Lebermoos-Flora Westpatagoniens und des südlichen Chile mit einer Einleitung von P. Dusén. Bih. Kongl. Svenska Vetensk.-Akad. Handl. 26, Afd. 3, 6: 1-69.

- 1901-1905. Species Hepaticarum. Vol.II. Georg \& Cie, Genève S.A., Genève.

- 1906-1909. Species Hepaticarum Vol. III. Georg \& Cie, Genève S.A., Genève.

- 1911. Die Lebermoose. In: C. Skottsberg, Botanische Ergebnisse der Schwedischen Expedition nach Patagonien und dem Feuerlande 1907-1909. Kongl. Svenska Vetensk.-Akad. Handl. 46(9): 1-92.

1917-1925. Species Hepaticarum Vol. VI. Georg \& Cie (Eds.), Genève S.A., Genève. 